\title{
The biological clock keeps ticking, but exercise may turn it back
}

\author{
O relógio biológico não para, mas o exercício físico pode atrasar o tempo
}

Andrea Deslandes

\begin{abstract}
Aging is an inevitable process that is associated to loss of functional capacities in several body systems, like the cardiovascular, the skeletal muscle mass, the osteoarticular and the neuro-immune-endocrine systems. Changes appear due to interactions between genetic factors and way of life, such as diet and sedentary life style. This review shows evidence from the past twenty years concerning the importance of physical exercise to reduce the deleterious effects of aging, regarding the improvement in functional performance, the prevention of diseases and increased longevity. Moreover, physical exercise improves the cognitive function and the mood. Aerobic and strength training collaborate with the prevention and treatment of mental diseases, which are mostly prevalent in older adults, like major depression, dementia and Parkinson's disease. Several mechanisms of neurobiological action are proposed to explain how exercise can actually reduce the effects of aging.
\end{abstract}

Key words: aging, physical activity, mental health, life style.

\section{RESUMO}

O envelhecimento é um processo inevitável. Está associado à perda progressiva da função de diversos sistemas, entre eles o sistema cardiovascular, musculoesquelético, osteoarticular e neuroimunoendócrino. Estas alterações acontecem devido à interação entre fatores genéticos e estilo de vida, como por exemplo, a alimentação e o sedentarismo. Esta revisão mostra as evidências da literatura dos últimos vinte anos quanto ao efeito do exercício físico na redução dos efeitos deletérios do envelhecimento, desde a melhora do desempenho à prevenção de doenças, aumento da longevidade, melhora da cognição e do humor. Tanto o treinamento aeróbio quanto o treinamento de força muscular contribuem na prevenção e no tratamento das doenças mentais mais prevalentes em idosos, como a depressão, as demências e a doença de Parkinson. Diversos mecanismos de ação neurobiológicos são propostos para explicar o efeito do exercício na redução do processo de envelhecimento.

Palavras-Chave: envelhecimento, atividade física, saúde mental, estilo de vida.

"If we could give every individual the right amount of nourishment and exercise, not too little and not too much, we would have found the safest way to health". Hippocrates, $460 \mathrm{BC}$

The importance of physical exercises for a healthy aging process is not a groundbreaking discussion; yet, it is evermore an extremely relevant issue. Hippocrates, over 400 years $\mathrm{BC}$, already suggested that the safest way to health would be the right amount of physical activity and nourishment. A long time has passed ever since, and until today studies confirm the relation between an active life style and health, demonstrating that the higher the level of physical capacity, the lower the risks of all-cause mortality ${ }^{1}$. Specifically, exercises contribute for the prevention of several cardiovascular and metabolic diseases, besides acting as an associated treatment to medication ${ }^{2}$. Also, recent studies have showed that exercise is not only good for the heart, lungs, vessels, muscles and bones, but it also improves the health of the brain $^{3}$. Physical exercise may contribute with the improvement of cognitive and behavioral functioning through neurobiological mechanisms necessary for neurogenesis, angiogenesis, synaptogenesis and plasticity. So, as aging speeds up degenerative processes, like sarcopenia, osteoporosis and cerebral atrophy, physical exercise increases lean body mass, bone mineral density and the formation of new neurons and neuroplasticity. The purpose of this paper is, therefore, to demonstrate that healthy aging is possible, even though human beings were not meant to survive with health as inactive individuals. 


\section{THE CLOCK IS TICKING, BUT EXERCISE CAN TURN IT BACK}

By observing each of the human body systems, it is possible to verify that at about the age of twenty our organism increases its reserves and its functional capacity gets to its maximum limit ${ }^{4}$. The cardiovascular capacity grows, as does the bone mineral density, which is at its highest levels, and so is the capacity for hormones production (especially sexual hormones like estrogen and testosterone). The brain completes its development and myelination of neurons reaches its peak. At this moment, metabolism is fast, muscles and bones are strong and the cerebral cortex swiftly processes new stimulus. After that, the human body begins to suffer decreases. Every decade it loses about $10 \%$ of its functions, such as muscular strength and cardiovascular conditioning. At the age of 60 , approximately $30 \%$ of the functional capacity or more is expected to decline, depending on possible diseases. This process of functional loss may come to its limit at the age of 90, when the individual becomes incapable of fulfilling basic daily activities independently. The heart starts to beat slower, despite the increased sympathetic activity. Muscles lose strength and lean mass, making difficult for a person to complete tasks apparently as simple as climbing stairs or standing up from a chair. Metabolism becomes slower, thus contributing for increased body fat and metabolic diseases. Bones lose their capacity of producing new cells; therefore, the balance between osteoblasts (production of new cells) and osteoclasts (degradation of existing cells) is affected, facilitating the process of osteoporosis. The good news is that all can be prevented, or at least contained, by the practice of physical exercises. Evidence from more than twenty years of research shows that exercises can improve the physical health of the elderly. Even those who have never exercised before may start a program of aerobic and strength training and benefit from its physiological and functional responses.

With reference to cardiovascular health, Paffenberger et al..$^{5}$ demonstrated in studies with Harvard alumni that the more time spent in physical activities, the less risks of cardiovascular diseases or all-cause mortality. Recent studies show that the mortality risk is $38 \%$ lower for those who achieve 5.1 to 6.0 metabolic equivalent (METs) ${ }^{1}$. Concerning bone health, since the 1990's studies of Drinkwater et al. ${ }^{6}$ showed greater mineral bone density in athletes who performed activities with higher overload, such as handball, basketball and weightlifting. Regarding muscles, over twenty years ago experiments by Fiatarone et al. ${ }^{7}$ showed the importance of strength training for frail nonagenarians. In this study, nonagenarians had up to $180 \%$ strength gain in just eight weeks of training. This strength gain was associated to increased mobility, since the greater the strength, the higher the speed to walk a six-meter distance. An impressive result of this study was the increase of the frail elders' independence after strength training. Two of them, who had started the study using walking canes, finished after eight months no longer needing this support. Also, another elder who could not rise from a chair without the help of his hands completed the intervention period able to get up using only the strength of his legs. Although these experiments were conducted during the 1990's, the past twenty years of research about the effect of physical exercises on the health of the elderly population have confirmed these authors' findings ${ }^{2}$.

\section{EXERCISE AND THE BRAIN: MOOD, ANXIETY AND COGNITION}

Although the positive effects of exercise over physical health are incontestable, its importance to mental health is not yet a consensus in literature. Not due to the lack of positive results, but because they have been little investigated. Since the 1970's, the seminal work of Spirduso ${ }^{8}$ has already demonstrated the differences between the reaction time of active and sedentary older adults. Active individuals showed better reaction time than their sedentary peers, confirming the idea that an active life style could also contribute to the better performance of the central nervous system (CNS). Many years later, evidence shows that physical exercises seem to contribute with the improvement of specific cognitive functions, such as memory and executive function, related to greater hippocampal volume, increased plasticity and better activation of frontal and parietal areas associated with cognition ${ }^{9-11}$. Aerobic ${ }^{9}$ and strength training ${ }^{12}$ improve the executive function among the elderly. This progress does not happen only due to social contact and the increase of cognitive stimulus provoked by the interaction and attention received from others. Exercises at an adequate intensity are necessary for the functional - hemodynamic, hormonal and neurobiological - adaptations to occur.

In addition to benefits related to the cognitive function, elders who practice physical activities seem to experiment better mood and sense of mastery, increase of resilience and self-efficacy ${ }^{13}$. Studies show that elders who are submitted to physical training, besides acutely reducing their levels of anxiety and negative affect ${ }^{14}$, boost their sense of mastery, that is, the perception that their locus of control is inside them, and not subject to any external factor ${ }^{13}$. The increase of selfefficacy and self-esteem contributes to the improvement in the quality of life of the elderly, thus confirming that benefits from physical exercise go far beyond strength gain and boost of cardiac capacity.

\section{EXERCISE AND MENTAL HEALTH: PREVENTION AND TREATMENT}

Along with aging, there is an increased prevalence and incidence of mental disorders, among which are depression 
and dementia. By 2050, 106.2 million new cases of Alzheimer's disease $(A D)$ are expected throughout the world. Today, the world cost of dementia averages US\$ 315,000 million per year. The annual cost per patient can reach US\$ 17,964. In this sense, cognitive decline and mental illnesses among elderly adults become great concerns to public health. Around $60 \%$ of the elders with cognitive decline suffer twice as many falls as those without any cognitive impairment, thus revealing that small cognitive deficits may be associated to greater risks of falls. The use of preventive interventions can delay disease progression in 12 months, therefore avoiding 9.2 million new $\mathrm{AD}$ cases in the world ${ }^{15}$. Exercise can contribute to decrease the risks of developing mental illnesses, besides collaborating with treatment to reduce the diseases' symptoms. Among non-pharmacological treatments, physical activity is indicated as a promising practice, receiving great attention in the international scientific literature produced in the beginning of this century ${ }^{16-18}$. Recent studies show the protective effect of exercise in cognitive functions and in combating the deleterious effects of stress and aging ${ }^{19-21}$.

The practice of physical activity is also associated with the decrease of diseases such as depression, $\mathrm{AD}$ and Parkinson's disease $(\mathrm{PD})^{22-24}$. In addition, researchers demonstrate how an exercise program can diminish symptoms and improve the patients' quality of life $\mathrm{e}^{25,26}$. This form of simple and low cost intervention leads to spending less in relation to hospitalization and medications, besides improving the independence for activities of daily living (ADLs) ${ }^{16,27}$. The reduction of falls and fatigue are other relevant aspects, since these are important concerns for elderly patients with mental illnesses ${ }^{28,29}$.

\section{Depression}

The effect of physical exercise is associated with the reduction of depression symptoms, increase of functional capacity, improvement of quality of life and alterations of cortical activity in depressed older adults ${ }^{3,25,30-35}$. Strength and aerobic training contribute to the increased response to treatment (50\% reduction of depression symptoms) and remission (reduction in depression scales to a cut-off score of asymptomatic classification). Blumenthal et al. ${ }^{32}$ verified that aerobic training (walking, running, biking) is as effective as the use of antidepressants (sertraline) to treat depression among the elderly. Furthermore, older adults also benefit from increased cardiovascular and functional capacities, something that does not occur with elders that only use medication. Singh et al..$^{35}$ demonstrate how a resistance exercise with intensity of $80 \%$ repetition maximum (1RM) is more efficient than the same exercise performed with low intensity $(20 \% 1 R M)$. Recently, trials conducted in our lab showed that aerobic training (30 minutes of walk on the treadmill, $60 \% \mathrm{VO}_{2 \max }$ ) associated with pharmacological treatment is more efficient than the use of antidepressants alone for treating major depression in elderly people. The results after six months ${ }^{31}$ and one year ${ }^{30}$ interventions show greater remission and response to treatment in the group of patients who performed the exercise program. Moreover, by the end of the study patients presented a cortical activity pattern similar to that of their elder healthy peers. This result was not observed in patients who did not practice exercises while using medication. Evidence shows that aerobic, as well as strength exercises, should be recommended as an additional treatment to the elderly with major depression, since it is a safe and low cost alternative to improve functional capacity and reduce depression symptoms. Also, it is important to observe that no studies presented adverse response in participating patients.

\section{Dementia and Parkinson's disease}

Besides its benefits for treating mood disorders, exercise is indicated as a strategic intervention for the prevention and non-pharmacological treatment of neurodegenerative diseases. In this sense, the risk of developing dementia is $32 \%$ lower among active older adults if compared to their sedentary peers ${ }^{36}$. Furthermore, the patients' physical activity level is directly associated with independence in activities of daily living, no matter how long they have been suffering from the disease ${ }^{37}$. The better the cardiovascular capacity, the greater the brain's total volume in patients with $\mathrm{AD}$, which is the most prevalent dementia ${ }^{38}$. In one of the first clinical studies, Palleschi et al. ${ }^{39}$ showed that aerobic training contributes with a favorable response in the cognitive function of $\mathrm{AD}$ patients. Over the past sixteen years, other studies also have demonstrated positive results in reducing depression symptoms ${ }^{40,41}$, increasing functional capacity ${ }^{42-44}$ and independence in activities of daily living ${ }^{26,42,43}$, thus improving the patient's and the caregiver's quality of life ${ }^{41}$, reducing the caregiver burden ${ }^{41}$ and maintaining or recovering cognitive functions ${ }^{39,43,45,46}$.

Although no studies have yet related adverse responses and physical exercise, Eggermont et al. ${ }^{47}$ questioned its use in patients suffering from dementia and cardiovascular risk. Recently, a case study conducted with a patient of vascular dementia and $\mathrm{AD}$ showed that regular walks during four months on the treadmill $\left(60 \% \mathrm{VO}_{2 \max }\right.$, twice a week) contributed to the increase of functional capacity, improvement of cognitive function and reduction of depression symptoms, as well as the reduction of caregiver burden and boost of patient's and caregiver's quality of life ${ }^{41}$. However, randomized controlled clinical trials must be conducted in order to support these initial findings.

Studies which investigate the effect of physical exercise on PD demonstrate a positive result concerning the patient's behavioral, cognitive and motor function ${ }^{3}$. Even though the physiotherapeutic intervention is the most investigated one, aerobic training, flexibility, balance and strength training presented benefits to the treatment of the disease. Some of the results observed with training are the reduction of tremors and muscle rigidity, as well 
as the improvement of balance and walk ${ }^{48}$. Experiments have also demonstrated the decreased risk of falls ${ }^{48}$ and enhancement of motor performance ${ }^{49}$. Although all types of training have showed favorable results, it is not yet determined which is precisely the best intervention and intensity for those patients ${ }^{3}$. Hirsch et al..$^{50}$ verified that despite the reduced risk of falls with balance training as well as combined (strength + balance) training, patients that practiced strength training maintained the acquired benefits for a longer period after detraining. Therefore, strength training seems to play an important role for patients. Moreover, the improvement of quality of life and behavioral function has been verified in recent studies ${ }^{51}$.

\section{Neurobiological mechanisms}

Many are the neurobiological mechanisms suggested for the improvement of the cognitive, behavioral and motor functions with physical exercise. For example, there is an increase of neurotransmitters (dopamine, norepinephrine, acetylcholine, serotonin), trophic factors (BDNF, IGF-1, GNF, NTN, VEGF), the activity of antioxidant enzymes (SOD, Catalase, Glutathione Peroxidase) and the production of neuromodulators associated to the sense of pleasure and the reduction of anxiety, such as opioids and endocannabinoids ${ }^{20,52,53}$. Exercise stimulates the production of these substances, which are consequently associated to the greater capacity of protein synthesis and mitochondrial activity, favoring the survival of cells. These alterations promote an increase of neurogenesis, angiogenesis, synaptogenesis and mitochondrial biogenesis (Figure). Considering the mitochondria's importance to maintain life and prevent diseases, exercises can serve as a mechanism for increasing enzyme capacity of the Krebs cycle and of the Electron Transport Chain, and a stimulus for bimolecular signals necessary to form new mitochondria.

In addition, trophic factors like BDNF and IGF-1 contribute to the inhibition of apoptosis, therefore favoring the maintenance of life and the function of cells. Moreover, hypothesis associates neurodegenerative diseases to the incapacity of immunologic response in the CNS. In this sense, exercise may collaborate by increasing the activity of nitric oxide synthases and the production of cytokines (IL-6, IL-10) ${ }^{54}$. This could boost immunologic response of astrocytes and microglia to fight the swelling caused by B-amyloid and $\alpha$-synuclein accumulation. With regards to longevity, studies reveal that exercise may help maintain the length of telomeres, which are reduced with aging ${ }^{55}$. In brief, Figure shows possible neurobiological mechanisms associated to physical exercise and the brain's health.

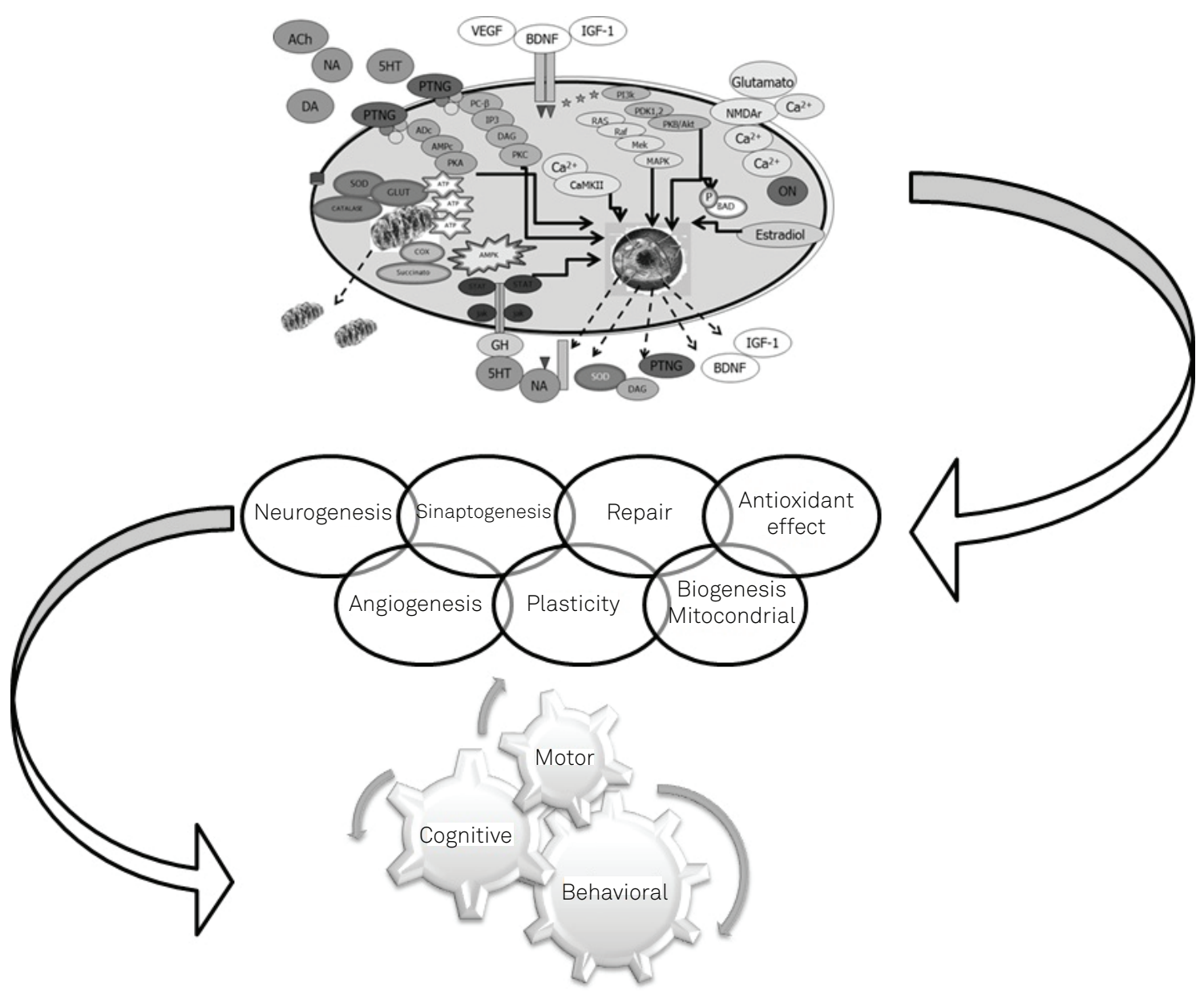

Figure. Neurobiological mechanisms of exercise on cognitive, behavioral and motor function. 


\section{HOW MUCH EXERCISE IS NEEDED FOR GOOD HEALTH?}

The American College of Sports Medicine $e^{56,57}$ and the World Health Organization (WHO) recommend at least 150 minutes of exercises per week to obtain benefits for health. Furthermore, the prescription of physical activity to the elderly should include aerobic exercises, strength training, flexibility, balance and motor coordination. Unfortunately, less than half of the population is physically active. Also, studies reveal this percentage is even lower among older adults, since up to $80 \%$ of them are inactive ${ }^{58}$. Among strategies to increase the adoption of exercises in the routine, counseling actions may contribute to reduce sedentary life style. According to the WHO, messages should be clear and simple, for example, "collect 150 minutes of weekly physical activity" or "make 30 minutes of moderate physical activity everyday". Another way to measure the level of spontaneous physical activity is by counting the number of steps per day. Trials using pedometers show that elders walk the average of 7,000 to 10,000 steps a day ${ }^{59}$. However, this is not the reality for most of them, specially for those diagnosed with mental diseases. Investigation shows that patients with Alzheimer's walk the average of 4,645 steps a day ${ }^{60}$. This is a much smaller amount than the minimum usually recommended for health. So, daily 30 minute walks, which correspond to an average of 3,000 steps, would be enough to increase the physical activity of these patients and rise to the number of steps indicated to this age group.

\section{FINAL REMARKS}

Even though the biological clock cannot be stopped, life style changes, such as stress management, healthy eating habits and adoption of physical activity, can slow down the aging process. Evidence of the impact of exercises over our cells' health and, therefore, over our functions are incontestable. Twenty years of research results concerning the effect of exercises on muscles, heart, bones and brain show there is not one safest and least expensive way to maintain an individual's health and independence. Physical exercise must be encouraged and incorporated into the population's habits, for it plays a fundamental role in preventive medicine. Our ancestors needed to be strong and fast to hunt, escape and survive. Thousands of years have passed, but the human being continues to require movement for a healthy way to survive.

\section{References}

1. Kokkinos P, Myers J, Faselis C, et al. Exercise capacity and mortality in older men: a 20-year follow-up study. Circulation 2010;122:790-797.

2. Chodzko-Zajko WJ, Proctor DN, Fiatarone Singh MA, et al. American College of Sports Medicine position stand. Exercise and physical activity for older adults. Med Sci Sports Exerc 2009;41:1510-1530.

3. Deslandes A, Moraes H, Ferreira C, et al. Exercise and mental health: many reasons to move. Neuropsychobiology 2009;59:191-198.

4. Kalache A. Envelhecimento no contexto internacional: a perspectiva da Organização Mundial de Saúde. In: Anais do I Seminário Internacional Envelhecimento Populacional: uma agenda para o final do século, 1996; Brasília. Brasília; 1996. p.13-15.

5. Paffenbarger RS Jr, Hyde RT, Wing AL, Hsieh CC. Physical activity, all-cause mortality, and longevity of college alumni. N Eng J Med 1986;314:605-613.

6. Drinkwater BL. 1994 C. H. McCloy Research Lecture: does physical activity play a role in preventing osteoporosis? Res Q Exerc Sport 1994;65:197-206.

7. Fiatarone MA, Marks EC, Ryan ND, Meredith CN, Lipsitz LA, Evans WJ. High-intensity strength training in nonagenarians. Effects on skeletal muscle. JAMA 1990;263:3029-3034.

8. Spirduso WW. Reaction and movement time as a function of age and physical activity level. J Gerontol 1975;30:435-440.

9. Colcombe SJ, Kramer AF, Erickson KI, et al. Cardiovascular fitness, cortical plasticity, and aging. Proc Natl Acad Sci U S A 2004;101: 3316-3321.

10. Kramer AF, Colcombe SJ, McAuley E, et al. Enhancing brain and cognitive function of older adults through fitness training. $J \mathrm{Mol}$ Neurosci 2003;20:213-221.

11. Erickson KI, Prakash RS, Voss MW, et al. Aerobic fitness is associated with hippocampal volume in elderly humans. Hippocampus 2009;19:1030-1039.
12. Cassilhas RC, Viana VA, Grassmann V, et al. The impact of resistance exercise on the cognitive function of the elderly. Med Sci Sports Exerc 2007;39:1401-1407.

13. Babyak M, Blumenthal JA, Herman S, et al. Exercise treatment for major depression: maintenance of therapeutic benefit at 10 months. Psychosom Med 2000;62:633-638.

14. Moraes $H$, Deslandes A, Silveira H, Arcoverde C, Alve H, Laks J. Effects of motor and cognitive dual-task performance in depressive elderly, healthy older adults, and healthy young individuals. Dement Neuropsychol 2011;5:198-202.

15. Brookmeyer R, Johnson E, Ziegler-Graham K, Arrighi HM. Forecasting the global burden of Alzheimer's disease. Alzheimers Dementia 2007;3:186-191.

16. Frazer CJ, Christensen H, Griffiths KM. Effectiveness of treatments for depression in older people. Med J Aust 2005;182:627-632.

17. Dunn AL, Trivedi MH, O'Neal HA. Physical activity dose-response effects on outcomes of depression and anxiety. Med Sci Sports Exerc 2001;33(Suppl):S587-597.

18. Moraes H, Deslandes A, Ferreira C, Pompeu FA, Ribeiro P, Laks J. O exercício físico no tratamento da depressão em idosos: revisão sistemática. Rev Psiquiatr Rio Gd Sul 2007;29:70-79.

19. Colcombe SJ, Erickson KI, Raz N, et al. Aerobic fitness reduces brain tissue loss in aging humans. J Gerontol A Biol Sci Med Sci 2003;58:176-180.

20. Radak Z, Chung HY, Goto S. Exercise and hormesis: oxidative stressrelated adaptation for successful aging. Biogerontology 2005;6: 71-75.

21. Radak Z, Chung HY, Koltai E, Taylor AW, Goto S. Exercise, oxidative stress and hormesis. Ageing Res Rev 2008;7:34-42.

22. Pope SK, Shue VM, Beck C. Will a healthy lifestyle help prevent Alzheimer's disease? Annu Rev Public Health 2003;24:111-132. 
23. Strawbridge WJ, Deleger S, Roberts RE, Kaplan GA. Physical activity reduces the risk of subsequent depression for older adults. Am J Epidemiol 2002;156:328-334.

24. Blay SL, Andreoli SB, Fillenbaum GG, Gastal FL. Depression morbidity in later life: prevalence and correlates in a developing country. Am J Geriatr Psychiatry 2007;15:790-799.

25. Blumenthal JA, Babyak MA, Moore KA, et al. Effects of exercise training on older patients with major depression. Arch Intern Med 1999;159:2349-2356.

26. Rolland Y, Pillard F, KlapouszczakA, et al. Exercise program for nursing home residents with Alzheimer's disease: a 1-year randomized, controlled trial. J Am Geriatr Soc 2007;55:158-165.

27. Gage H, Storey L. Rehabilitation for Parkinson's disease: a systematic review of available evidence. Clin Rehabil 2004;18:463-482.

28. Carvalho Ade M, Coutinho Eda S. Dementia as risk factor for severe bone fractures among the elderly. Rev Saude Publica 2002;36: 448-454.

29. Garber CE, Friedman JH. Effects of fatigue on physical activity and function in patients with Parkinson's disease. Neurology 2003;60:1119-1124.

30. Deslandes AC, Moraes $\mathrm{H}$, Alves $\mathrm{H}$, et al. Effect of aerobic training on EEG alpha asymmetry and depressive symptoms in the elderly: a 1-year follow-up study. Braz J Med Biol Res 2010;43:585-592.

31. Silveira $\mathrm{H}$, Deslandes $\mathrm{AC}$, de Moraes $\mathrm{H}$, et al. Effects of exercise on electroencephalographic mean frequency in depressed elderly subjects. Neuropsychobiology 2010;61:141-147.

32. Blumenthal JA, Babyak MA, Doraiswamy PM, et al. Exercise and pharmacotherapy in the treatment of major depressive disorder. Psychosom Med 2007;69: 587-596.

33. Singh NA, Clements KM, Fiatarone MA. A randomized controlled trial of progressive resistance training in depressed elders. J Gerontol A Biol Sci Med Sci 1997;52:M27-35.

34. Singh NA, Clements KM, Singh MA. The efficacy of exercise as a longterm antidepressant in elderly subjects: a randomized, controlled trial.J Gerontol A Biol Sci Med Sci 2001;56:M497-504.

35. Singh NA, Stavrinos TM, Scarbek Y, Galambos G, Liber C, Fiatarone Singh MA. A randomized controlled trial of high versus low intensity weight training versus general practitioner care for clinical depression in older adults. J Gerontol A Biol Sci Med Sci 2005;60:768-776.

36. Larson EB, Wang L, Bowen JD, et al. Exercise is associated with reduced risk for incident dementia among persons 65 years of age and older. Ann Intern Med 2006;144:73-81.

37. Arcoverde C, Deslandes A, Rangel A, et al. Role of physical activity on the maintenance of cognition and activities of daily living in elderly with Alzheimer's disease. Arq Neuropsiquiatr 2008;66:323-327.

38. Kalaria RN, Maestre GE, Arizaga R, et al. Alzheimer's disease and vascular dementia in developing countries: prevalence, management, and risk factors. Lancet Neurol 2008;7:812-826.

39. Palleschi L, Vetta F, De Gennaro E, et al. Effect of aerobic training on the cognitive performance of elderly patients with senile dementia of Alzheimer type. Arch Gerontol Geriatr 1996;22:47-50.

40. Williams CL, Tappen RM. Exercise training for depressed older adults with Alzheimer's disease. Aging Ment Health 2008;12:72-80.

41. Arcoverde C, Deslandes A, Araujo N, Laks J. Ejercicio físico y demencia mixta: un caso clínico. Psicogeriatría 2011;3:93-96.

42. Santana-Sosa E, Barriopedro MI, López-Mojares LM, Pérez M, Lucia A. Exercise training is beneficial for Alzheimer's patients. Int J Sports Med 2008;29:845-850.
43. Kwak YS, Um SY, Son TG, Kim DJ. Effect of regular exercise on senile dementia patients. Int J Sports Med 2008;29:471-474.

44. Tappen RM, Roach KE, Applegate EB, Stowell P. Effect of a combined walking and conversation intervention on functional mobility of nursing home residents with Alzheimer disease. Alzheimer Dis Assoc Disord 2000;14:196-201.

45. Arkin SM. Student-led exercise sessions yield significant fitness gains for Alzheimer's patients. Am J Alzheimers Dis Other Demen 2003;18:159-170.

46. Heyn P, Abreu BC, Ottenbacher KJ. The effects of exercise training on elderly persons with cognitive impairment and dementia: a metaanalysis. Arch Phys Med Rehabil 2004;85:1694-1704.

47. Eggermont L, Swaab D, Luiten P, Scherder E. Exercise, cognition and Alzheimer's disease: more is not necessarily better. Neurosci Biobehav Rev 2006;30:562-575.

48. Ebersbach G, Edler D, Kaufhold O, Wissel J. Whole body vibration versus conventional physiotherapy to improve balance and gait in Parkinson's disease. Arch Phys Med Rehabil 2008;89: 399-403.

49. Caglar AT, Gurses HN, Mutluay FK, Kiziltan G. Effects of home exercises on motor performance in patients with Parkinson's disease. Clin Rehabil 2005;19: 870-877.

50. Hirsch MA, Toole T, Maitland CG, Rider RA. The effects of balance training and high-intensity resistance training on persons with idiopathic Parkinson's disease. Arch Phys Med Rehabil 2003;84: 1109-1117.

51. Tanaka K, Quadros AC Jr, Santos RF, Stella F, Gobbi LT, Gobbi S. Benefits of physical exercise on executive functions in older people with Parkinson's disease. Brain Cogn 2009;69:435-441.

52. Dishman RK, Berthoud HR, Booth FW, et al. Neurobiology of exercise. Obesity 2006;14:345-356.

53. Dietrich A, McDaniel WF. Endocannabinoids and exercise. Br J Sports Med 2004; 38:536-541.

54. Petersen AM, Pedersen BK. The anti-inflammatory effect of exercise. J Appl Physiol 2005;98:1154-1162.

55. Cherkas LF, Hunkin JL, Kato BS, et al. The association between physical activity in leisure time and leukocyte telomere length. Arch Intern Med 2008;168:154-158.

56. Chodzko-Zajko WJ, Proctor DN, Fiatarone Singh MA, et al. American College of Sports Medicine position stand. Exercise and physical activity for older adults. Med Sci Sports Exerc 2009;41: 1510-1530.

57. Garber CE, Blissmer B, Deschenes MR, et al. American College of Sports Medicine position stand. Quantity and quality of exercise for developing and maintaining cardiorespiratory, musculoskeletal, and neuromotor fitness in apparently healthy adults: guidance for prescribing exercise. Med Sci Sports Exerc 2011;43: 1334-1359.

58. Hallal PC, Dumith SC, Bastos JP, Reichert FF, Siqueira FV, Azevedo MR. Evolução da pesquisa epidemiológica em atividade física no Brasil: revisão sistemática. Rev Saude Publica 2007;41: 453-460.

59. Tudor-Locke C, Craig CL, Aoyagi Y, et al. How many steps/day are enough? For older adults and special populations. Int J Behav Nutr Phys Act 2011;8:80.

60. Lima RA, Freitas CMS, Smethurst WS, Santos CM, Barros MVG. Nivel de atividade física em idosos com doença de Alzheimer mediante aplicação do IPAQ e de pedômetros. Rev Bras Ativ Fís Saúde 2010;15:180-185 